\title{
OS FESTIVAIS DE MÚSICA POPULAR BRASILEIRA: VEÍCULO DE VEZ E DE VOZ
}

\author{
SELMA SUELY TEIXEIRA \\ Mestre em Literatura Brasileira pela UFPR
}

\begin{abstract}
No início da década de 60, o Brasil inaugurava uma nova capital, constituída no Planalto Central a mil quilômetros da costa atlântica, e para compensar o Rio de Janeiro pela perda da condição de capital federal, Juscelino Kubitschek cria o Estado da Guanabara, que tem como primeiro governador, Carlos Lacerda.
\end{abstract}

Nos discursos políticos, jornais, livros e panfletos, expressões como "a vontade do povo" ou a "consciência popular" e "os magnos interesses da Nação" ou "os verdadeiros interesses nacionais", começam a aparecer freqüentemente.

Inicia-se a conscientização de que é fundamental um "exame de consciência nacional", do contrário, o Brasil continuará a ser "um país que progride mas não se enobrece, um país sem mensagens para 0 mundo (. . .) à espera que taumaturgos ou chefes de bandeiras mais ou menos providenciais venham solucionar os nossos problemas." (1)

O desenvolvimento real só é possível a partir do momento em que povo e nação estejam unidos no mesmo objetivo. E em nome do povo e da nação, são idealizadas reformas constitucionais e agrárias, realizados plebiscitos e planos governamentais, promulgadas leis e decretos, presidentes são empossados e renunciam, surgem institutos e sindicatos, projetos faraônicos são desenvolvidos, conspirações e golpes acontecem.

$\mathrm{Na}$ área cultural, Vinícius de Moraes lança sua Antologia Poética; Astrud Gilberto conquista o maior prêmio musical dos Estados Unidos da América, o Gramy, com a gravação de "Garota de Ipanema", de Tom Jobim e Vinícius de Moraes; Anselmo Duarte dirige "O pagador de promessas", de Dias Gomes que irá ganhar a Palma de Ouro em Cannes; Ziraldo lança Pererê; Dorival Caymmi se apresenta no show de Andy Williams para interpretar "Das Rosas"; João Gilberto realiza concertos em várias cidades americanas; Tom Jobim é convidado para assinar um contrato milionário nos Estados Unidos; surge A maçã no escuro, de Clarice Lispector; Glauber Rocha, "com uma câmara na mão e uma idéia na cabeça", dirige o seu primeiro filme: "Barravento"; Stanislaw Ponte Preta publica Tia Zulmira e eu; Eduardo Portela lança Literatura e Realidade Nacional; a coleção Cadernos do Povo é lançada pela Civilização Brasileira; "Vidas Secas", de Nélson Pereira das Santos, e "Deus e o Diabo na Terra do Sol", de Glauber Rocha são premiados no festival de Cannes; Dalton Trevisan lança Cemitério de Elefantes; nomes como Gianfrancesco Guarnieri, Flávio Rangel, Augusto Boal, Ruy Guerra, Ferreira Gullar, Baden Powel. Millôr Fernandes, Plínio Marcos e João Cabral de Mello Neto, se consolidam no cenário brasileiro.

A época é marcada por uma série de debates em torno do papel que artistas e intelectuais poderiam e deveriam exercer enquanto cidadãos que também sofriam os reflexos das medidas sufocadas tomadas contra a nação, e não apenas meros denunciadores dessas medidas.

E em 1962, surge o Manifesto do CPC, que se apresenta "como declaração de princípios da vanguarda popular revolucionária no campo da cultura" (2) e que tem como destinatário, "o intelectual e o artista 'alienados', que fazem 'arte pela arte' ". Optando por ser "parte integrante do povo", o artista popular revolucionário dos CPCs pretende, ao levar esse povo a se conscientizar das condições materiais da realidade brasileira e das conseqüências dessas condições para sua vida, alcançar o caminho da liberdade política e econômica que lavará ao desenvolvimento pleno da nação.

1964 encontra o meio cultural produzindo e criando movimentos, como o Cinema Novo, o "poema-práxis: um evento revolucionário", de Mário Chamie, e o show Opinião, de OduvaldoVianna Filho e Paulo Pontes: "dado novo: alegria, euforia, festa", fala em "unidade e integração nacionais". No programa do show, a opinião dos autores e intérpretes de que "a música popular é tanto mais expressiva quanto mais tem uma opinião, quando se alia ao povo na captação de novos sentimentos e valores necessários para a evolução 
social, quando mantém vivas as tradições de unidade e integrações nacionais. A música popular não pode ver o público como simples consumidor de música; ele é fonte e razão de música".(3)

No ano seguinte surgem os festivais de música popular brasileira, lançando compositores como Chico Buarque, Edu Lobo, Geraldo Vandré e Caetano Veloso, que colocando as incertezas e esperanças do povo como centro de suas composições, fazem sua opção pelos "sem poder na sociedade" identificandose assim com as aspirações fundamentais do povo de existir numa sociedade onde "ele se dirija por si mesmo".

Característica do espírito nacional dos anos 60, esse cantar o povo encontra nos Festivais de Música Popular Brasileira da década, o seu veículo de vez e de voz.

"Arrastão", de Edu Lobo e Vinícius de Moraes, vencedora do I Festival Nacional da MPB, realizado pela TV Excelsior, de São Paulo, caracteriza já pela escolha do próprio título e tema - arrastão é uma rede que varre o fundo do mar carregando todo e qualquer peixe -, o abandono do individual em favor do retrato de uma ação coletiva.

\title{
ARRASTÃo - Edu Lobo e Vinícius de Moraes
}

\author{
Eh! tem jangada no mar \\ Eh! hoje tem arrastão \\ Eh! todo mundo pescar \\ Chega de sombra, João \\ Já ouviu, \\ Olha $o$ arrastão entrando no mar sem fim \\ Eh! meu irmão me traz lemanjá pra mim \\ Olha 0 arrastão entrando no mar sem fim \\ Eh! meu irmão me traz lemanjá pra mim \\ Minha Santa Bárbara, me abençoai \\ Quero me casar com Janaína \\ Eh! puxa bem devagar \\ Eh! já vem vindo arrastão \\ Eh! é rainha do mar \\ Vem, vem na rede, João \\ Pra mim, \\ Valha-me Deus Nosso Senhor do Bonfim \\ Nunca jamais se viu tanto peixe assim \\ Valha-me Deus Nosso Senhor do Bonfim \\ Nunca jamais se viu tanto peixe assim
}

\begin{abstract}
João, nome próprio representativo de uma coletividade - a humanidade em geral - abandona "a sombra" e, atendendo a uma série de convocações ("Eh! tem jangada no mar/Eh! hoje tem arrastão/Eh! todo mundo pescar"), entrega-se à divindade que comanda os pescadores ("Quero me casar com Janaína"), entrando por fim na rede coletiva.
\end{abstract}

Tendo escolhido pescadores como arrebanhadores de homens, os autores recuperam através de lembranças de ensinamentos religiosos, divindades e entidades cultuadas pela maior parte do povo brasileiro, num exemplo do sincretismo religioso pertinente à nossa formação étnica ("Eh! meu irmão me traz lemanjá pra mim/Minha Santa Bárbara, me abençoai/Quero me casar com Janaína (...) Valha-me Deus Nosso Senhor do Bonfim ...")

O aparecimento de verbos no gerúndio ("olha o arrastão entrando no mar sem fim (...) Eh! já vem vindo o arrastão ...") caracteriza uma ação em movimento; o entendimento do coletivo como um todo orgânico, capaz de modificar o comportamento nacional.

"Porta-estandarte", de Geraldo Vandré e Fernando Lona vence em julho de 1966, o II Festival Nacional de 


\section{PORTA-ESTANDARTE - Geraldo Vandré e Fernando Lona}

Olha que a vida é tão linda

E se perde em tristezas assim

Desce teu rancho cantando

Essa tua esperança sem fim

Deixa que a tua certeza

Se faça do povo a canção

Pra que teu povo cantando

O teu canto ele não seja em vão

Eu vou cantando a minha vida enfim,

Cantando, e canto sim,

E não cantava se não fosse assim

Levando, pra quem me ouvir

Certezas e esperanças pra trocar

Por dores e tristezas que bem sei

Um dia ainda vão findar

Um dia que vem vindo

E que eu vivo pra cantar

$\mathrm{Na}$ avenida girando,

Estandarte na mão pra anunciar

Olha que a vida tão linda, tão linda,

Perdida, perdida

Tão linda, perdida.

Palavra-chave do poema, a palavra "canção" e suas variantes (cantando, cantava, canto, cantar) constituem a mola propulsora da ação. Assim, o chamamento ao cantar ("Desce teu rancho cantando/Essa tua esperança sem fim/Deixa que a tua certeza/Se faça do povo a canção/Pra que teu povo cantando/O teu canto ele não seja em vão"), reflete a crença de que "as dores e tristezas um dia ainda vão findar", sendo essa a bandeira do poeta, transformado agora em porta-estandarte: o cantar como esperança para o difícil momento vivido pelo país após a instalação do golpe militar.

Em outubro do mesmo ano, tem início o Festival da MPB da TV Record, de São Paulo que teve duas vencedoras: "A banda", de Chico Buarque de Hollanda e "Disparada", de Geraldo Vandré, por exigência do público assistente.

Os festivais começam a ser vistos como elemento representativo da escolha popular. Às medidas proibitivas de participação em debates públicos, agremiações e eleições, a juventude respondia cantando e consagrando seus eleitos, investidos da consciência dos valores comuns e das aspirações coletivas.

\section{A BANDA - Chico Buarque de Hollanda}

Estava à toa na vida

O meu amor me chamou

Pra ver a banda passar

Cantando coisas de amor

A minha gente sofrida

Despediu-se da dor

Pra ver a banda passar

Cantando coisas de amor

O homem sério que contava dinheiro parou

$O$ faroleiro que contava vantagem parou 
A namorada que contava as estrelas parou

Para ver, ouvir e dar passagem

A moça triste que vivia calada sorriu

A rosa triste que vivia fechada se abriu

E a meninada toda se assanhou

Pra ver a banda passar

Cantando coisas de amor

$O$ velho fraco se esqueceu do cansaço e pensou

Qu'inda era moço pra sair no terraço e dançou

A moça feia debruçou na janela

Pensando que a banda tocava pra ela

A marcha alegre se espalhou na avenida e insistiu

A lua cheia que vivia escondida surgiu

Minha cidade toda se enfeitou

Pra ver a banda passar

Cantando coisas de amor

Mas para meu desencanto

$O$ que era doce acabou

Tudo tomou seu lugar

Depois que a banda passou

E cada qual no seu canto

Em cada canto uma dor

Depois da banda passar

Cantando coisas de amor

DISPARADA - Geraldo Vandré e Théo

Prepare o seu coração, / Pras coisas que eu vou contar Eu venho lá do sertão / E posso não lhe agradar Aprendi a dizer não / Ver a morte sem chorar E a morte, o destino, tudo / Estava fora de lugar Eu vivo pra consertar / Na boiada já fui boi Mas um dia me montei / Não por um motivo meu Que junto comigo houvesse / Que qualquer querer tivesse Porém por necessidade / $O$ dono de uma boiada, Cujo vaqueiro morreu / Boiadeiro muito tempo Laço firme, braço forte / Muito gado, muita gente, Pela vida segurei / Seguia como num sonho E boiadeiro era o rei / Mas o mundo foi rodando Nas patas do meu cavalo / Nos sonhos que fui sonhando As visões se clareando / As visões se clareando Até que um dia acordei / Então não pude seguir Valente, lugar tenente / E dono de gado a gente Porque gado a gente mata / Tange, ferra, engorda e marca Mas com gente é diferente / Se você não concordar Não posso me desculpar / Não canto pra enganar Vou pegar minha viola / Vou deixar você de lado Vou cantar noutro lugar / Na boiada já fui boi, Boiadeiro já fui rei, Nem por mim, nem por ninguém, Que junto comigo houvesse / Quem quisesse, ou quem pudesse

Por qualquer coisa de seu / Por qualquer coisa de seu Querer mais longe que eu / Mas o mundo foi rodando, Nas patas do meu cavalo / E já que um dia montei Agora sou cavaleiro / Laço firme, laço forte De um reino que não tem rei. 
Convite à participação de todos em um cortejo que altera o mundo e natureza por onde passa, "A Banda" tem na canção e no amor, os caminhos que levam à esperança de uma alegria constante, capaz de fazer as cidades se enfeitarem "pra ver a banda passar / cantando coisas de amor".

Os versos predominantemente heptassilábicos, dão voz ao ritmo característico da fala, refletindo "um contentamento descontente, uma dor que desatina a doer, abrindo a ferida que dói e não se sente, fazendo penetrar em corações rasgados, um fogo que arde sem se ver." (4)

Características do estilo de Chico Buarque de Hollanda, a construção em blocos entremeados por palavras intercambiáveis, já aparece em "A Banda".

\section{"O homem sério que contava dinheiro parou / O faroleiro que contava vantagem parou / \\ A namorada que contava estrelas parou / \\ Para ver, ouvir e dar passagem \\ A moça triste que vivia calada sorriu \\ A rosa triste que vivia fechada se abriu ..."}

Sendo que o verso que corta o bloco, ("Para ver, ouvir e da passagem") reforça a idéia das mudanças proporcionadas pela passagem da banda.

O poema está construído no tempo passado, dos 28 verbos, 23 estão no passado, refletindo uma época em que natureza e homem comungavam a mesma alegria: "a moça triste que vivia calada sorriu/a rosa triste que vivia fechada se abriu", em oposição ao presente, onde "cada qual (está) no seu canto", com a sua dor.

Preferindo a ação de contar à de cantar, o poeta de "Disparada" aprende a dizer não, e a " ver a morte sem chorar". A atitude de "viver pra cantar um dia que vem vindo", de "Porta-estandarte", se converte agora na ação imediata do "consertar (o que) está fora de lugar". O levar o canto "pra quem me ouvir", se transforma em deixar de lado aquele que não concorda e "cantar noutro lugar".

A o denunciar injustiças e diferenças sociais "Porque gado a gente marca/Tange, ferra, engorda e mata/Mas com gente é diferente", o poeta resgata e constróe a consciência nacional, transformando-se assim numa espécie de agente mediador entre o povo recebedor dessas injustiças e os fatos que as provocam.

Características da literatura de cordel são recuperadas no processo de desenvolvimento temático de "Disparada". Assim, da mesma forma que nas "cantorias", o poema inicia com uma apresentação do "cantador", onde ele narra suas proezas passadas, seu local de origem e que vitórias conquistou, e prossegue com uma aparente variação de assuntos onde o fator social se apresenta como valor principal: o poema como veículo que, ao colocar seu criador em contato com o meio, faz com que ele se torne conhecedor das coisas do mundo.

Tal como os cantadores de cordel, o poeta de "Disparada" finaliza colocando-se como instrumento do pensamento coletivo, não cantando "pra enganar(...) nem por mim, nem por ninguém."

Em novembro de 1966, tem início o Festival Internacional da Canção, no Rio de Janeiro, promovido pela Rede Globo. Realizado em duas etapas: nacional e internacional, o I FIC classificou em primeiro lugar a música "Saveiros" de Dorival Caymmi e Nelson Motta, que retoma a tese de que o meio é determinante no destino do homem. O resultado não recebeu o apoio do público, dividido entre "Dia das rosas", de Luís Bonfá e Maria Helena Toledo e "Canção a medo", de Sérgio Bittencourt. 


\section{SAVEIROS - Dori Caymmi e Nelson Motta}

Nem bem a noite terminou

Vão os saveiros para o mar

Levam no dia que amanhece

As mesmas esperanças

Do dia que passou

Quantos partiram de manhã

Quem sabe quantos vão voltar

Só quando o sol descansar,

E se os ventos deixarem,

Os barcos vão voltar

Quantas histórias pra contar

E em cada vela que aparece

Um canto de alegria

De quem venceu no mar

Em 1967, "Ponteio", de Edu Lobo vence o Festival da Record, que classifica em segundo lugar "Domingo no Parque", de Gilberto Gil, em terceiro lugar "Roda Viva", de Chico Buarque de Hollanda e em quarto, "Alegria, alegria", de Caetano Veloso. Letras como "A estrada e o violeiro", de Sydnei Miller, "Eu e a brisa", de Johnny Alf e "O cantador", de Nelson Motta, concorrem para a categoria de melhor letra, o que constata o alto nível da produção artística da época.

PONTEIO - Edu Lobo

Era um, era dois, era cem,

Era o mundo chegando e ninguém

Que soubesse que eu sou violeiro

Que me desse ou amor, ou dinheiro

Era um, era dois, era cem

Vieram pra me perguntar

Ô você pra onde vai, de onde vem

Diga lá o que tem pra contar

Parado no meio do mundo

Senti chegar meu momento

Olhei pro mundo e nem via

Nem sombra, nem sol e nem vento

Quem me dera agora

Eu tivesse a viola pra cantar

Quem me dera agora

Eu tivesse a viola pra cantar

Era um dia, era claro, quase meio,

Era um canto calado, sem ponteio

Violência, viola, violeiro

Era a morte, em redor mundo inteiro

Era um dia, era claro, quase meio

Tinha um que jurou me quebrar

Mas não lembro de dor nem receio

Só sabia das coisas do mar

Jogaram a viola no mundo

Mas fui lá no fundo buscar

Se eu tomo a viola, ponteio

Meu canto não posso parar, não

Quem me dera agora

Eu tivesse a viola pra cantar, 


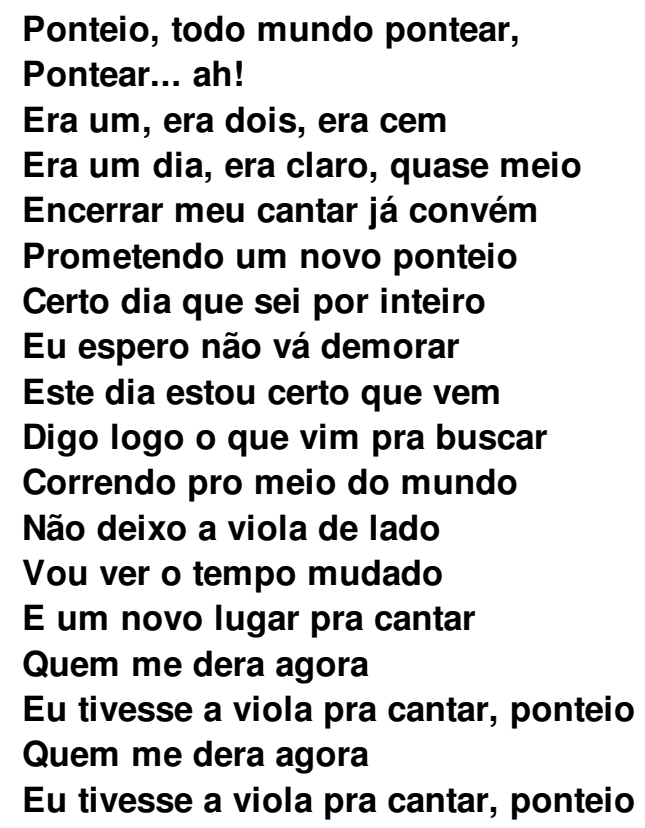

Vivendo em uma época que vê o regime ditatorial legitimado por uma Constituição, e a promulgação de uma Lei de Segurança Nacional que levará civis a enfrentar cortes marciais, Edu Lobo vai buscar no mágico "era uma vez" dos contos de fadas, a maneira de expressar a esperança que todos tem de "ver o tempo mudado/E um novo lugar pra cantar".

Reforçando os objetivos de "socializar, informar, despertar emoções e desenvolver o sentimento de compreenção e simpatia humanas" (5) comuns às histórias infantis, a letra de "Ponteio" também se estrutura como os contos de fadas, através de uma linguagem simples, e plena de ação, de um espaço e tempo indeterminados e indefinidos ("Era um, era dois, era cem/ Era o mundo chegando e ninguém (...) Ô você pra onde vai, de onde vem / Diga lá o que tem pra contar / Parado parado no meio do mundo ...")., e de um conteúdo que explica os fatos que envolvem o "herói" ("Era o mundo chegando e ninguém / Que soubesse que eu sou violeiro / Que me desse ou amor, ou dinheiro (...) Parado no meio do mundo/Senti chegar meu momento/ Olhei pro mundo e nem via / Nem sombra, nem sol e nem vento (...) Tinha um que jurou me quebrar / Mas não lembro de dor nem receio / Só sabia das coisas do mar / Jogaram a viola no mundo / Mas fui lá no fundo buscar / Se eu tomo a viola, ponteio / Meu canto não posso parar, não ...").

Numa reatualização das provas iniciatórias comuns aos contos infantis, o poeta é perguntado "pra onde vai, de onde vem / Diga lá o que tem pra contar" e se sente sozinho num mundo "sem sombra, sem sol e sem vento". Sem a viola pra cantar, vê "a morte, em redor mundo inteiro" e enfrenta "um que jurou me quebrar", sem lembrar "de dor nem receio", e corre pro fundo do mundo buscar a viola que , tal qual a varinha de condão é portadora de poderes mágicos, permitindo o "preenchimento das fissuras dando novamente à terra, sua solidez." (6)

Presente em todo poema, a fórmula mágica do "era um" como que costura as partes em que o poema se divide, "tecendo a trama dos destinos, comentando e questionando valores, para concluir a mensagem pela qual o poeta é responsável". (7)

Em outubro do mesmo ano, "Margarida", de Gutemberg e Guarabyra vence a fase nacional do II FIC, do Rio de Janeiro, deixando "Travessia", de Milton Nascimento em segundo lugar e "Carolina", de Chico Buarque, em terceiro. Mais uma vez, o júri do Festival Internacional se opunha à vontade popular, que pedia para "soltar a voz na estrada".

MARGARIDA - Gutemberg e Guarabyra

Andei, terras do meu reino em vão

Por senhora que perdi

$E$ por quem fui descobrir 
Não me crer mais rei e aqui me encerrei

Sou cantor e cantarei

Que em procuras de amor morri, ai

Dor que no meu tempo dói

Que destróes assim de mim

Bem sei que eu achei, enfim

$E$ que adiantou a dor,

Mas me queimou

Pois por não saber de amor

Ela ainda rainha está

E ela está em seu castelo, olê, olê, olá

E ela está em seu castelo, olê, seus cavaleiros

Ora peçam que apareça

Pois por mais que eu ofereça

Mais me evita essa senhora

Eu já fui rei, já fui cantor

Vou ser guerreiro, um perfeito cavaleiro

Armadura, escudo, espada,

Pra seguir na escalada,

Belo motivo, é por amor que vou lutando

E pelas pedras do castelo

Como eu já vou retirando

E retirando uma pedra, olê, olê, olá

Mais uma pedra não faz falta, olê, seus cavaleiros

Que ainda correm pelo mundo,

Ouçam só por segundo, eu acabo de vencer

Retirei pedras de orgulho, majestades,

Deixei todas de humildades, de amores sem reinado

Ela então se me rendeu

Eu já fui rei, já fui cantor, já fui guerreiro

E agora enfim sou companheiro,

Da mulher que apareceu

E apareceu a Margarida, olê, olê, olá

E apareceu a Margarida, olê, seus cavaleiros

Apresentando todas as características da cantiga de amor medieval portuguesa, "Margarida" é o registro da confissão do sofrimento de um trovador, que, peregrino, padece pelo amor de sua senhora ("Andei, terras do meu reino em vão/ Por senhora que perdi/ E por quem fui descobrir/ Não me crer mais rei e aqui me encerrei/ Sou cantor e cantarei/ Que em procuras de amor morri, ai/ Dor que no meu peito dói/ Que destróes assim de mim/ Bem sei que eu achei, enfim/ E que adiantou a dor,/ Mas me queimou/ Pois por não saber de amor/ Ela ainda rainha está")

O amor que o poeta expressa é sempre respeitoso e platônico, numa atitude de vassalagem ("Ora peçam que apareça/ Pois por mais que eu ofereça/ Mais me evita essa senhora/Eu já fui rei, já fui cantor/ Vou ser guerreiro, um perfeito cavaleiro/ Armadura, escudo, espada,/ Belo motivo, é por amor que vou lutando / E pelas pedras do castelo/ Como eu já vou retirando").

Vencida a indiferença da amada, o poeta se declara vencedor ("Retirei pedras de orgulho, majestades,/ Deixei todas de humildades, de amores sem reinado/ Ela então se me rendeu/ Eu já fui rei, já fui cantor, já fui guerreiro/ E agora enfim, sou companheiro/ Da mulher que apareceu").

Tal como a poesia trovadoresca, "Margarida" sedimenta-se no veio folclórico, recuperando da canção de roda, o motivo do poema. 
Onde está a Margarida, olê, olê, olá (bis)

Ela está no castelo, olê, olê, olá (bis)

Ela está no castelo, olê, seus cavaleiros

Mas eu desejava vê-la, olê, olê, olá (bis)

Mas eu desejava vê-la, olê, seus cavaleiros

Mas o muro é muito alto, olê, olê, olá (bis)

E tirando um pedra, olê, olê, olá (bis)

Uma pedra não faz falta, olê, olê, olá (bis)

Apareceu a Margarida, olê, olê, olá (bis)

"Bem-vinda", de Chico Buarque de Hollanda vence em 1968, o IV

Festival de MPB, da TV Record, de São Paulo.

BEM-VINDA - Chico Buarque de Hollanda

Dono do abandono e da tristeza

Comunico oficialmente

Que há lugar na minha mesa

Pode ser que você venha por mero favor

Ou venha coberta de amor

Seja lá como for

Venha sorrindo

Ah! Bem-vinda, bem-vinda, bem-vinda

Que o luar está chamando

Que os jardins estão florindo

E eu estou sozinho

Cheio de anseios e esperança

Comunico a toda gente

Que há ;lugar na minha dança

Pode ser que você venha

Morar aqui,

Ou venha pra se despedir

Não faz mal

pode vir até mentindo

Ah! Bem-vinda, bem-vinda, bem-vinda

Que o meu pinho está chorando

Que o meu samba está pedindo

E eu estou sozinho

Venha iluminar meu quarto escuro

Venha entrando como $o$ ar puro

Todo novo da manhã

Venha minha estrela, madrugada

Venha minha namorada

Venha amada, venha urgente

Venha irmã,

Bem-vinda, bem-vinda, bem-vinda

Que essa aurora está custando

Que a cidade está dormindo

E eu estou sozinho

Certo de estar perto da alegria

Comunico finalmente,

Que há lugar na poesia

Pode ser que você tenha um carinho pra dar 
Ou venha pra se consolar

Mesmo assim pode entrar

Que é tempo ainda

Ah! Bem-vinda, bem-vinda, bem-vinda

Ai que bom que você veio

E você chegou tão linda

E eu não cantei em vão

Bem-vinda, bem-vinda,

Bem-vinda, bem-vinda,

Bem-vinda no meu coração

O cantar a esperança é retomatdo nesse poema de Chico Buarque de Hollanda que, se autodeterminando " dono do abandono e da tristeza", se reconhece sozinho e cercado de incertezas ("Pode ser que você venha por mero favor/Ou venha coberta de amor (...) Pode ser que você tenha um carinho pra dar/Ou venha pra se consolar"), e pede, em nome do luar e dos jardins floridos, do pinho e do samba, da aurora e da cidade, que a esperança volte e chegue tão linda, que seja capaz de iluminar o quarto escuro, "entrando como o ar puro todo novo da manhã".

No mesmo ano, Chico Buarque de Hollanda em parceria com Tom Jobim vence o III FIC nas fases nacional e internacional, com "Sabiá". Nesse mesmo festival, Geraldo Vandré conquista o público com "Pra não dizer que não falei de flores" transformada pouco tempo depois, em uma espécie de hino das frentes de resistência ao regime.

SABIÁ - Chico Buarque e Tom Jobim

Vou voltar

Sei que ainda vou voltar

Para o meu lugar, foi lá

E é ainda lá

Que eu hei de ouvir cantar

Uma sabiá

Uma sabiá

Vou voltar,

Sei que ainda vou voltar

Vou deitar à sombra

De uma palmeira

Que já não há

Colher a flor que já não dá

E algum amor talvez possa espantar

As noites que eu não queria

Lhe anunciar um dia

Vou voltar

Sei que ainda vou voltar

Não sei se vai ser em vão

Que fiz tantos planos de me enganar

Como fiz enganos de me encontrar

Como fiz estradas de me perder

Fiz de tudo e nada de te esquecer

Vou voltar,

Sei que ainda vou voltar

Para o meu lugar, foi lá

E é ainda lá

Que eu hei de ouvir cantar

Uma sabiá

Vou voltar

Sei que ainda vou voltar 

E é pra ficar
Sei que o amor existe
Eu não sou mais triste
E que a nova vida já vai chegar
E que a solidão vai se acabar
E que a nova vida já vai chegar
E que a solidão vai se acabar

Texto paródico, "Sabiá" opõe uma pátria ideal, onde ainda se ouve cantar sabiás, a uma pátria saqueada e depredada, onde não há mais palmeiras em cuja sombra se possa deitar, ou flores que possam ser colhidas, e noites que não se queiram, criando uma tensão entre um passado marcado pela nostalgia, e um futuro marcado pela esperança ("Vou voltar/Sei que ainda vou voltar/Para o meu lugar, foi lá/E é ainda lá/Que eu hei de ouvir cantar/Uma sabiá")

O presente é marcado pela negação ("Vou deitar à sombra/De uma palmeira/Que já não há/Colher a flor que já não dá/E algum amor talvez possa espantar/As noites que eu não queria/Lhe anunciar um dia"), caracterizando o exílio de toda uma geração.

Palavras-chave do texto-base de Gonçalves Dias, são recuperadas aqui, como: sabiá, palmeira, flor, amor (características da terra natal) e o advérbio lá que reforça o sentido de uma volta decidida ("E é pra ficar") porque lá, é a terra do poeta.

O sentimento da saudade em "Sabiá" tem um sentido social: saudade, de tudo o que se perdeu, e não meramente espacial, como no poema de Gonçalves Dias.

Em 1969, Paulinho da Viola vence o V Festival da Record com "Sinal Fechado".

\section{SINAL FECHADO - Paulinho da Viola}

- Olá, como vai?

- Eu vou indo e você, tudo bem?

- Tudo bem, eu vou indo, correndo, pegar meu lugar no futuro, e você?

- Tudo bem, eu vou indo, em busca de um sono tranqüilo, quem sabe?

- Quanto tempo ...

- Pois é, quanto tempo ...

- Me perdoe a pressa é a alma do nosso negócio

- Qual, não tem de quê. Eu também só ando a cem ...

- Quando é que você telefona? Precisamos nos ver por aí,

- Pra semana, prometo, talvez nos vejamos, quem sabe?

- Quanto tempo ...

- Pois é, quanto tempo ...

- Tanta coisa que eu tinha a dizer, mas eu sumi na poeira

das ruas

- Eu também tenho algo a dizer, mas me foge à lembrança

- Por favor telefone, eu preciso beber alguma coisa,

rapidamente,

- Pra semana ...

- O sinal ...

- Eu procuro você

- Vai abrir, vai abrir

- Prometo, não esqueço

- Por favor, não esqueça, não esqueça

- Adeus. 
Poema articulado através de uma linguagem fragmentada, telegráfica e clicherizada, "Sinal fechado" retrata um cotidiano que tem na pressa de cada um, a conquista de motivos individuais e particulares. Já não se canta mais a esperança de dias que virão, já não se canta mais o amor. Canta-se apenas a perda no dia-a-dia, daquilo que em algum tempo foi conquistado.

"Cantiga por Luciana", de Paulinho Tapajós e Edmundo Souto, vencedora das fases nacional e internacional do IV FIC, retoma o sentido da natureza e do despertar da inocência, característicos do romantismo.

Dividido em duas estrofes de cinco versos intercaladas por um estribilho, "Cantiga por Luciana" apresenta a sustentação formal do gênero cantiga, surgido no período medieval.

A convocação para o cantar coletivo da esperança, característica do espírito nacional dos anos 60 , voltase para o subjetivo e individual cantar de um poeta "cansado de esperar só".

\title{
CANTIGA POR LUCIANA - Paulo Tapajós/Edmundo Souto
}

\author{
Manhã, no peito de um cantor \\ Cansado de esperar, só \\ Foi tanto tempo que nem sei \\ Das tardes tão vazias \\ Por onde andei \\ Luciana, Luciana, \\ Sorriso de menina, \\ Dos olhos de mar, \\ Luciana, Luciana, \\ Abrace essa cantiga \\ Por onde passar \\ Nasceu, na paz de um beija-flor \\ Em verso, em voz de amor \\ Já desponta aos olhos da manhã \\ Pedaços de uma vida \\ Que abriu-se em flor. \\ Luciana, Luciana, \\ Sorriso de menina \\ Dos olhos de mar \\ Luciana, Luciana, \\ Abrace essa cantiga \\ Por onde passar.
}

No início da década de 70, o Brasil tinha uma população de 99.901 .037 habitantes, conforme revela o Oitavo Recenseamento Geral do Brasil. " $5 \%$ de brasileiros mais ricos que absorviam $27,3 \%$ da renda nacional em 1960 , passam a arrecadar $36,3 \%$ em 1970 e os $50 \%$ mais pobres vêem reduzida sua participação na renda de $27,8 \%$ para $13,1 \% "$.(8)

O Presidente Garrastazu Médici declara numa visita ao Nordeste, que "a economia pode ir bem, mas a maioria do povo vai mal", e divulga o seu programa de metas destinado a construir o Brasil-Potência. Como programas de impacto, incluem-se a construção da Transmazônica, inacabada até hoje, e a declaração verbal de que o limite do mar territorial passa de doze para duzentas milhas.

São criados o INCRA - Instituto Nacional de Colonização e Reforma Agrária, a FUNABEM - Fundação Nacional do Bem Estar ao Menor e o MOBRAL - Movimento Brasileiro de Alfabetização.

$\mathrm{Na}$ área cultural, Antônio Cândido escreve o ensaio Dialética da Malandragem; surgem os periódicos Bomdia, Pif-Paf, Em tempo e Politika; Henfil cria "Zeferino", "Bode Orelana" e "Graúna"; surgem o cinema marginal e o novíssimo.

Com os maiores compositores da MPB no exílio, com os órgãos de comunicação sob censura, e com a 
onda ufanista imposta ao país pelos serviços de propaganda da ditadura ("Eu te amo meu Brasil", "Brasil, ame-o ou deixe-o", "Brasil, eu fico"), o grande sucesso musical do ano é "Pra frente, Brasil" de Miguel Gustavo, composto especialmente para a Copa do Mundo do México, que consagrou o Brasil Tri-Campeão Mundial, e a grande vencedora do V FIC, "BR-3", de Antonio Adolfo e Tibério Gaspar.

D a Venezuela, Geraldo Vandré canta sua "Pátria Amada", espécie de nova "Canção do Exílio", que encontra no amor, o sentido da permanência.

A pátria recompensa assim o poeta, com a certeza de que será sempre amado por ela, num reconhecimento da doação do seu cantar.

\author{
PÁTRIA AMADA - Geraldo Vandré \\ Se é pra dizer adeus \\ Pra não te ver jamais \\ Eu que dos filhos teus \\ Fui te querer demais \\ No verso que hoje chora \\ Pra me fazer capaz \\ Da dor que me devora \\ Quero dizer-te mais \\ Que além de adeus agora \\ Eu te prometo em paz \\ Levar comigo afora \\ $O$ amor demais. \\ Amado meu \\ Sempre serás \\ Quem me guardou \\ No teu cantar \\ E me levou \\ Além do meu \\ Além do céu \\ E além do mar \\ Amado meu \\ Que além de mim se deu \\ Não se perdeu \\ E nem se perderá.
}

\title{
NOTAS DE REFERÊNCIA
}

1. LEITE, Dante Moreira. $O$ caráter nacional brasileiro. 3. ed. São Paulo: Pioneira, 1976. p. 301

2. CHAUí, Marilena. Seminários. São Paulo: Brasiliense, 1983. p. 86 (O nacional e o popular na cultura brasileira)

3. HOLLANDA, Heloísa Buarque de. Impressões de viagem: cpc, vanguarda e desbunde: 1960/70. 2. ed. São Paulo, Brasiliense, 1981. p. 32

4. ANDRADE, Carlos Drummond de. A banda. Correio da Manhã, 14 out. 1966.

5. CARVALHO, Bárbara Vasconcelos de. A literatura infantil: visão histórica e crítica. 2. ed. São

Paulo, EDART, 1982. p. 57

6. Idem, p.63

7. Idem, p.61

8. RIBEIRO, Darcy. Aos trancos e barrancos: como o Brasil deu no que deu. Rio de Janeiro:

Guanabara Dois, 1985. (2039) 
1. BENEVIDES, Maria Victoria. O governo Jânio Quadros. São Paulo:Brasiliense,1981. 87p. (Tudo é história,30)

2. CARVALHO, Bárbara Vasconcelos de. Do conto na literatura infantil. In _. A literatura infantil: visão histórica e crítica. 2.ed. São Paulo: DART,1983. p.54-8

3. _. O universo mágico dosa contos maravilhosos. In: _. A literatura infantil: visão histórica e crítica. 2.ed. São Paulo: EDART, 1983. p.59-61

4. CARVALHO, Gilberto. Chico Buarque: análise poética-musical. Rio de Janeiro: CODECRI, 1982. 186p.

5. CHAUÍ, Marilena. Seminários. São Paulo: Brasiliense, 1983.103p. (O Nacional e o Popular na cultura brasileira)

6. COHN-BENDIT, Daniel. Onde estão os rebeldes de 68? Leia, São Paulo, VII (75) : 3-6. 1985

7. DAGHLIAN, Carlos (org.) Poesia e música. São Paulo: perpectiva, 1985. 200p.

8. DIEGUES JR. M. Literatura de cordel. Rio de janeiro: FUNARTE, 1975. 38p. (Cadernos de folclore,2)

9. HERZ, Daniel. A história secreta da Rede Globo. 9.ed. Porto Alegre: Tchê, 1987. 300p.

10. HOLLANDA, Heloísa Buarque de \& Gonçalves,Marcos A. Cultura e participação nos anos 60.2

ed. São Paulo: Brasiliense, 1982. 102p. (Tudo é história, 41)

11. 1981. 199p.

Impressões de viagem: cpc, vanguarda e desbunde-1960/70. 2ª ed. São Paulo:Brasiliense,

12. HOLLANDA, Sérgio Buarque de. Raízes do Brasil. 14 ed. Rio de Janeiro: José Olympio, 1981. 158p. (Documentos Brasileiros, 1)

13. LEITE, Dante Moreira. $O$ caráter nacional brasileiro. 3 ed. São Paulo: Pioneira, 1976. 339p.

14. MENESES, Adélia Bezerra de. Desenho mágico: poesia e política em Chico Buarque. São

Paulo: HUCITEC, 1982. 246P.

15. __ (org.) Chico Buarque de Hollanda: seleção de textos, notas, estudo bibliográfico, histórico e crítico. São Paulo: Abril Educação, 1980. 106p. (Literatura Comentada)

16. MEDEIROS, Paulo de Tarso. A aventura da Jovem Guarda. São Paulo: Brasiliense, 1984. 86p.

(Tudo é hitória, 92)

17. NETO, Ramalho. Histórinha do dasafinado: bossa-nova. Rio de Janeiro: Vecchi, 1965.

18. RIBEIRO, Darcy. Aos trancos e barrancos: como o Brasil deu no que deu. Rio de Janeiro:

Guanabara Dois, 1985.

19. SANT'ANNA, Affonso Romano de. O interregno da música popular: 1967- 1973. In: Música

Popular e Moderna Poesia Brasileira. Petrópolis: Vozes, 1978. p.97-111 